Sakarya Üniversitesi İlahiyat Fakültesi Dergisi

Journal of Sakarya University Faculty of Theology

ISSN: 2146-9806 | e-ISSN: 1304-6535

Cilt/Volume: 22, Say1/Issue: 41, Y11/Year: 2020 (Haziran/June)

\title{
İbn Sînâ ve Molla Sadrâ'da Varlık Kavramının Teşkîk Niteliği
}

The Quality of Tashkīk of the Concept of Being in Ibn Sìnā and Mullā Șadrā

\section{Fevzi Yiğit}

Dr. Öğr. Üyesi, Nevşehir Hacı Bektaş Veli Üniversitesi, İlahiyat Fakültesi, İslam Felsefesi Ana Bilim Dalı - Assistant Professor, Nevsehir Haci Bektas Veli University, Faculty of Theology, Department of Islamic Philosophy.

fevziyigit58m@hotmail.com

https://orcid.org/0000-0001-9420-5186

\section{Makale Bilgisi - Article Information}

Makale Türü/Article Type: Araştırma Makalesi/ Research Article

Geliş Tarihi/Date Received: 30/03/2020

Kabul Tarihi/Date Accepted: 08/05/2020

Yayın Tarihi/Date Published: 15/06/2020

Atıf/Citation: Yiğit, Fevzi. “İbn Sînâ ve Molla Sadrâ'da Varlık Kavramının Teşkîk Niteliği". Sakarya Üniversitesi İlahiyat Fakültesi Dergisi 22/41 (2020): 57-80. https://doi.org/10.17335/sakaifd.711785

İntihal: Bu makale, iThenticate yazılımı ile taranmış ve intihal tespit edilmemiştir. Plagiarism: This article has been scanned by iThenticate and no plagiarism detected.

Copyright $($ Published by Sakarya Üniversitesi İlahiyat Fakültesi - Sakarya University Faculty of Theology, Sakarya/Turkey. 


\section{İbn Sînâ ve Molla Sadrâ'da Varlık Kavramının Teşkîk Niteliği}

\section{Öz}

Metafiziğin ana konusu olan varlığın, kapsamı altındakilere hangi anlamda söyleneceği konusu, İslam felsefesinin ontolojiye dair en önemli sorunlarından birisidir. Yani varlık, bütün mevcutlar üzere eşit anlamda mı yoksa dereceli olarak mı söylenir? Dereceli olarak söylenmesine teşkîk denir. Aslında varlık-mahiyet, zorunlu-mümkün gibi ayrımlar da bir açıdan bu problemin çözümüne katııı. Zihin bu çözümü yapabilmek için mevcutları Tanrı-âlem veya özne-nesne gibi ayrımlara tâbi tutar. Sonrasında ise teşkîk fikri sayesinde bu ayrımları aşmaya çalışır. Zihin, teşkîk fikrinin tam olarak farkına varamaması durumunda -Aristoteles örneğinde olduğu gibi- Tanrı ile evren arasında ontolojik aykırılık ve kopukluklar olduğu düşüncesine kapılır. Bu makalede ulaşımaya çalışılan hedefler şunlardır: Varlığın teşkîki niteliği onun basit olduğu fikrine dayanır. Eğer böyle olmasaydı varlık bileşenlerine ayrılacak ve her mevcutta farklı bir şey olarak karşımıza çıkacaktı. Varlık güçlülük-zayıflık, kemal-noksanlık, öncelik-sonralık, intiyaçsızlık-fakirlik, nedensonuç vb. gibi açılardan dereceli bir yapıya sahiptir. Kısacası varlığın teşkîk niteliği "varlık, mevcutların birleşmelerini ve farklılaşmalarını sağlayan asıldır" şeklinde formüle edilebilir.

Anahtar Kelimeler: İslam Felsefesi, Mantık, Varlık, Teşkîk, Nur, Mahiyet.

\section{The Quality of Tashkīk of the Concept of Being in Ibn Sīnā and Mullā Șadrā}

\section{Abstract}

The problem of calling the things in scope of the existence which is the main topic of metaphysics is the most important theme of ontology in Islamic philosophy. In other words, is existence called equally or gradually? Calling it gradually is tashkik (gradation). Tashkīk and dichotomies such as existence-essence, necessary-possible are also come out to solve this problem. Mind is subject to divide the beings like God-universe or subject-object. Afterwards, tries to overcome these divisions by the idea of tashkīk. In the case of not grasping the idea of tashkik thoroughly -as in the case of Aristotle- gets the idea that there are ontological conradictions and disunities between God and universe. The goals of this study are as follows: The quality of tashkik of the existence is based upon the idea that it is simple. If not, it will be decomposed and will become a different thing in each being. In addition, existence has a gradual structure such as strength-weakness, posteriority-anteriority, cause-effect. Thus, the gradual quality of the existence can be formulized as follows: "Existence is the essence that ensures unity and disunity of beings."

[You may find an extended abstract of this article after the bibliography.]

Keywords: Islamic Phylosophy, Logic, Tashkīk, Being, Nūr, Essence.

\section{Giriş}

Bu makalede, İbn Sînâ (öl. 428/1037) ve Molla Sadrâ (öl. 1050/1641) esas alınarak bazı İslam filozoflarının teşkîk (dereceli anlamdaşlık) konusundaki görüşleri konu edilmektedir. Makalenin amacı, metafiziksel anlamda "varlık" kelimesinin kavranmasında önemli meselelerden birisini mümkün olduğunca belirginleştirmeye çalışmaktır. Öne çıkan ana probleme gelince İslam filozofları nezdinde "varlık kavramının üzerine söylendiği ve kapsamı altına aldığı fertlere teşkîki olarak söylenmesinin ne anlama" geldiğidir. Eski Yunan'da herhangi bir filozof, Tanrı ile âlemin aynı anlamda var olduğunu hatta âlemin ezeli olduğunu dile getirmekte en azından dini açıdan herhangi bir sakınca duymamakta iken İslâm filozoflarının aynı rahat tavrı sergilemeyeceği açıktır. 
İşte bu sebeple İslam düşüncesinde Tanrı ile âlemin varlık ismini hangi anlamda ve ne biçimde paylaştıkları önemli bir tartışma konusudur. Ve yine varlık/vücut kelimesinin Tanrı'ya isim olarak verilip verilemeyeceği tartışmasıyla metafiziğin asıl konusunun varlık mı yoksa Tanrı mı olduğu tartışması benzer bir tartışmadır.

Kümülatif bir ilim olan felsefeye İslam filozoflarının birçok katkısı olduğu bilinen bir gerçektir. Görülen o ki varlığın teşkîki niteliği meselesi de bunlardan birisidir. Çünkü bu meseleyi, Aristoteles'in (öl. MÖ 322) Organon ve Metafizik kitabında doğrudan bir araştırma konusu olarak incelemediği görülür. Hatta ilk dönem İslam filozoflarının da metafizik araştırmalarında varlık konusunu işlerken bu meseleye yer vermedikleri ifade edilmelidir. Şu halde meselenin alt yapısının İbn Sînâ tarafından oluşturulduğu, takipçileri yanında Sühreverdî'nin (öl. 587-1191) de buna katkı yaptığı söylenmelidir. Bununla birlikte konuyu daha çok öne çıkaran isim Molla Sadrâ'dır.

Filozofları teşkîk fikrine ulaştıran sorun şu sorularla araştırılabilir: Varlık ismi bütün mevcutlara hangi anlamda yüklenir? Tanrı ile âlem aynı anlamda mı vardır? Örneğin Tanrı ile herhangi bir taş aynı varlık yüklemini paylaşacaksa bu ne anlama gelmektedir? Tanrıya göre âlem gerçek mi yoksa mecazi mi bir var oluşa sahiptir? Âlem gerçek bir varoluşa sahipse Tanrının gerçekliğine göre gerçeklik seviyesi nedir? Vacip Varlık ile mümkün varlık arasında bir fark var mıdır? Fark yoksa nasıl olmakta da mümkün varlık zorunlu varlıktan zorunluluk kazanmaktadır? Bu durumda mümkün varlık zorunludan, varlık mı yoksa zorunluluk mu almaktadır? Veya bu ikisi birbirinden ayrılmaz mı? Çünkü nihayetinde varlık varsa zorunluluk da olmak durumundadır. Şu halde varlığın önüne zorunlu, mümkün ve hâdis gibi sıfatların konulması meselenin kolayca çözülmesine imkân vermemektedir. İşte bütün bu soruların nihai cevabı olarak İbn Sînâ'nın varlığın teşkîki niteliğe sahip olduğu fikrini ortaya attı̆̆ı söylenebilir.

Varlığın birliği-çokluğu, basit oluşu ve mertebeli bir yapıya sahip oluşu düşünceleri teşkîk fikrinin temelini oluşturan diğer meselelerdir. Basit olanın farklılaşmaması, yapısının bozulmaması ve başka bir şeyin varlığına ihtiyaç duymaması onun birliğiyle ancak anlam bulmaktadır. Bir olmakla birlikte o yapısı gereği her şeyin varlık nedenidir. Her ne kadar bileşik mevcutları var kılsa da o, bu durumdan etkilenmez. Çünkü varlık birdir ve zorunludur.

Bilindiği üzere varlık-mahiyet ayrımı önemli bir ayrımdır. Bu ayrım apriori varlık ve dış dünyadaki mevcutların çokluğu fikrine dayanır. Buradaki zorluk ayrımın dış dünya ve zihinde farklı biçimlerde gerçekleşmesinde saklıdır. Zihinde yer alan mevcutların tasavvur edilebilmeleri için bir açıdan varlığa ihtiyaç duymadıkları ve yine zihnin dış dünyadaki mevcutları mahiyetleri olmaksızın tasavvur edemediği görülmektedir. Dış dünyada bulunmaları açısından ise mevcutların varlık zemininde var oldukları, nedensellik bağlamı içerisinde birbirlerine bağlandıkları ve maddi seviyede birbirlerinden görece 
ayrımlara tâbi oldukları görülmektedir. Şu halde mahiyet sadece zihinsel bir ayrımın ürünüdür, denilebilir. Böyleyse dış dünyadaki farklılaşmanın izahı mümkün değildir. Eğer mahiyet gerçek bir ayrımın ürünüyse dış dünyadaki mevcutların mahiyet ve varlıklarının birbirinden ayrı olarak var olması gerekir. Bu ise ayrımın işe yaramadığı anlamına gelir. Bu sebeple İbn Sînâ'nın mahiyetleri zihinsel ayrımlar olarak kabul ettiğini müşahede etmekteyiz. Bu durumda mevcutların diş dünyadaki farklılıklarının nedeni varlıklarının yine kendisidir. Peki, mevcutları hem birleştiren hem de ayıran nedir? Bunun cevabı, varlık ve onun teşkîki niteliğidir.

Fârâbî (öl. 339/950) adını koymasa da mantıki ve felsefi anlamda meseleye referans oluşturacak tartışmaları yapmıştır. Nasîrüddin Tûsî (öl. 672-1274) üstadı İbn Sînâ gibi sınırlı anlamda teşkîki savunmuş, Sühreverdî ise varlık karşısında mahiyeti asıl kabul ettiği için sadece mahiyette teşkîki kabul etmiş; teşkîk kavramını kullanmasa da nurun dereceli olarak var olduğunu iddia etmiştir. Son olarak Molla Sadrâ varlığın mahiyet karşısında asıl gerçek olduğunu ve varlığın dereceli olmak kaydıyla bütün mevcutlara aynı anlamda söylendiğini ileri sürmüştür. Yani İbn Sînâ'nın sınırlı teşkîk anlayışını genişletmiştir. Sadrâ ile birlikte hâkim olan eğilim varlığın teşkîki alana sokulması; mahiyetlerin teşkîki alanın dışına itilmesi olmuştur. ${ }^{1}$

\section{Teşkîk Kavramının Mantıksal Anlamı}

Felsefe ile dil arasında köken ve gelişimleri açısından bir tür nedensellik bağlantısı olduğu söylenebilir. Şöyle ki, insan dile getirip kavramlaştırabildikleri sayesinde ancak felsefe yapabilmektedir. Her ne kadar düşüncenin aktarımında başka yolların varlığından söz edilse de evrensel bir düşünce ancak kelime ve kavramlar üzerinden dolaşıma girebilir. Bununla birlikte neredeyse sınırsız diyebileceğimiz düşünceleri sınırlı kelimelerle ifade etmek, ne kullanışlıdır ne de mümkündür. Yani manalar sonsuz, kelimeler ise sonlu olmak durumundadır. Bilindiği üzere buradaki niceliksel eşitsizlik önemli bir problemdir. Bu problemin yarattığı sıkıntıdan kurtulmak için kelimelere farklı anlamlar yüklemek üzere eş sesli (müşterek), eşit anlamlı (mütevâtı) ve dereceli anlamdaş (müşekkek) kelimelerin kullanılması yoluna gidilmiştir.

Teşkîk/müşekkek Arapça bir kavram olup şüphe kökünden elde edilmiştir. ${ }^{2}$ Teşkîk; insanın karşıt veya karışık iki şey arasında kalması veya ona bu

1 Molla Sadrâ, el-Hikmetü'l-müte'âliye fì esfâri'l-erba'a, thk. Ali Ekber Reşad (Tahran: Bunyâd-i Hikmet-i İslâmi-yi Șadrâ, 1380), 1/44. Descartes'e göre Tanrı'nın gücü dışında varlığını sürdürebilecek başka bir yaratık olmadı̆̆ından Skolastikte töz adı Tanrı'ya ve yaratıklara göre aynı anlamda verilmemiştir. Descartes, Felsefenin Ilkeleri, çev. Mesut Akın (İstanbul: Say Yayınları, 1995), 89.

2 Muhittin Mâcit, "Teşkîk”, Türkiye Diyanet Vakfı İslâm Ansiklopedisi (İstanbul: TDV Yayınları, 2011), 40/567; İbrahim Mustafa vd., el-Mu'cemü'l- vasît (İstanbul: Çağrı Yayınları, 1989), 490. 
ikisinin tercih edilemeyecek derecede eşit gözükmesidir. Bu durum bazen karşıtların kendisi veya karışıklardaki sıfatların benzerliğinden bazen de karşıtlar arasında ayırt edici sıfatların yokluğundan kaynaklanır. ${ }^{3}$ Kısacası teşkîki kavramların nereye dâhil edileceği noktasında şüphe duyulmuş ve bu yüzden böyle isimlendirilmişlerdir. ${ }^{4}$ Buna göre diş dünyadaki kökenlerinde benzerlikler içeren nesne veya sıfatların insan zihninde şüphe ve tereddüde sebep olması dolayısıyla bu nesne ve sıfatlara teşkîk ismi verilmiştir. Yani teşkîk kavramının gelişmesinde sıfatların mevsuflarındaki dereceli farklılı̆̆ı etkili olmuştur. ${ }^{5}$ Başka bir ifadeyle teşkîki kavramlar; sadece anlamları yönünden tek bir manayı ifade etmek için değil, aynı zamanda bu anlamın temsil edilen varlıklardaki yön, cihet ve derece farklarını da ifade etmek için üretilmişlerdir. ${ }^{6} \mathrm{Bu}$ yönden bu kavramlar varlığı, -varlığa bağlı olarak gerçeklik kazanan- cevher, sıfat ve arazları da kuşatmıştır.

Dil bilim paralelinde mantık biliminde "bir kelime bir veya birçok anlama" veya "birçok kelime bir tek anlama" delâlet etmek üzere kullanılmıştır. Teşkîki kavramlar birinci gruba, eş anlamlı kelimeler ikinci gruba dâhil edilmiştir. ${ }^{7}$ Mantık ilminde teşkîk "müşterek genel bir niteliğin fertleri üzerine eşit olarak değil de farklı seviyelerde söylenmesi" şeklinde tanımlanmıştır. Buna verilebilecek örnek ise beyaz kelimesidir. ${ }^{8}$ Musa b. Meymûn (öl. 601/1204) Delâletü'l-ḥâirîn kitabının mukaddemesinde kitabının yazılış gayesini Tanrının isimlerinin manasını açıklamak olarak tayin eder. Hemen peşi sıra müşterek, mütevâtı, müsteâr ve müşekkek isimler arasında yaşanan karmaşaya atıfta bulunarak Tanrı'nın sıfatlarının doğru anlaşılmasını buraya bağlar. $\mathrm{O}$, müşekkek isimlere bazen mütevâtı bazen müşterek denildiğini belirtir. ${ }^{9}$

Başka bir tanıma göre, mantıkta "bir lafzın çeşitli tikel varlıklar arasındaki ortak anlama farklı derecelerde delâlet etmesi teşkîk", "eşit derecede delâlet etmesi tevâtu" terimiyle ifade edilir. Teşkîk üç kısımda değerlendirir: Birincisi, öncelik ve önceliğinin yokluğu yönünden kavramın ifade ettiği anlamın farklılaşması ki örneğin var olmakta birleşen Vacip ve mümkün varlık kavramı arasında bu yönde bir fark vardır. İkincisi önce ve sonra olmada

3 Râgib el-İsfehânî, Müfredât elfâzi'l-Ḳur'ân, nşr. Safvân Adnân Dâvudî (Dimeşk: Daru'l-Ḳalem, 1992), 461.

4 Mâcit, “Teşkîk”, 567.

5 İbrahim Mustafa vd., el-Mu'cemü'l-vasît, 491.

6 Ahmet Pirinç, Molla Hâdi Sebzevâri'nin Metafizik Görüşleri (Elazığ: Fırat Üniversitesi, Sosyal Bilimler Enstitüsü, Doktora Tezi, 2015), 72.

7 Mâcit, “Teşkîk”, 567.

8 İbrahim Mustafa vd., el-Mu'cemü'l-vasît, 491.

9 Musa b. Meymûn, Delâletü'l-hâiirîn, çev. Osman Bayder - Özcan Akdağ (Kayseri: Kimlik Yayınevi, 2019), 35. 
teşkîktir. Yine varlık kavramı manasının oluşmasında bir kısmı diğer bazısından daha öncedir. Şöyle ki varlık anlamının Vacip'te hâsıl olması mümkünde hâsıl olmasından daha öncedir. Üçüncüsü ise güç ve zayıflıkta teşkîktir. Bu açıdan Vacip'in varlığı mümkünün varlığından daha güçlüdür. ${ }^{10}$ Allâme Hillî (öl. 726-1325) bu taksimi dile getirirken zikredilenlerden farklı olarak "mevcut" kelimesinin cevhere ve arazlara yüklenmesini; bir de sebep-sonuç arasindaki öncelik sonralık ilgisini örnek olarak verir. ${ }^{11}$

Aristoteles, Organon'un Kategoriler kitabının başında üç tür isimden bahsetmektedir. Bunlardan birincisi eş sesli (homonim/müşterek) kelimelerdir. Bunların adı bir; anlamları ise farklıdır. Örneğin resimdeki insan ile dışarıdaki insanı karşılayan kelime aynıdır ancak misdakları farklıdır. Aynı şekilde hayvan kelimesi insan ve kediyi farklı anlamlarda karşılar. İkincisi ise hem isim birliği hem de anlam özdeşliği olan eş anlamlı (sinomim/mütevâtı) kelimelerdir. Yine hayvan kelimesi insan ve kediyi aynı anlamda tanımlar. Son olarak "hal" yönünden bir başkasından farklı olmakla beraber, ortak bir isme göre adlandırılan nesnelerin isimlerine aynı kökten gelen (paronim/müştak) kelimeler denilir. Örneğin gramer kelimesinden gramerci, cesaret kelimesinden cesaretli kelimesi türetilir. ${ }^{12}$ Aristoteles'in bu tasnifine girmeyen kelimelerin tasnifi yönünde tarihi süreç içerisinde değişik görüşler ileri sürülmüştür. Bu bağlamda teşkîki kavramlar, bu tasnifte nereye yerleştirileceğine karar verilemeyen kelimeleri tanımlamak için kullanılmıştır. ${ }^{13}$

Aristoteles, Metafizik kitabında aynı kökten gelen kelimeleri (paronimleri) konu edinirken bunların çeşitli anlamları bir ve aynı şeyle ilgili olduğunu, fakat bir ve aynı şeyi ifade etmediğini, bununla birlikte eş sesliler gibi de olmadığını aktarır. Buna örnek olarak "tıbbî" kelimesini verir. Çünkü "tıbb̂̂” kelimesi hasta, doktor, hastane, ilaç vb. gibi sağlıkla ilgili şeyler hakkında kullanılmakta olup onlardaki ortak bir doğayı ifade etmekle görevlidir. ${ }^{14}$

Dilde mevcut olan ve Aristoteles'in altını çizdiği bu kullanım, -İbn Sînâ tarafından müşekkek kavramlar grubuna dâhil edilse de- tam anlamıyla teşkîki karşılamamaktadır. Asıl teşkîk, klasik Aristoteles mantık geleneği içerisinde tümellerde bulunabilir. Buna göre tümeller arasında biri evrensel olarak uygulanabilir, diğeri eşdeğer veya belirsiz biçimde uygulanabilir olan ikili bir ayrım yapılmıştır. Birinci anlamıyla nefis kavramı, eşit anlamda bütün

10 Seyyid Şerif Cürcânî, Kitâbü't-Ta'rîfât (Beyrut: Dâru'l-Kitâbü'l-Arab, 1983), 58-59.

11 Allâme Hillî, Cevherü'n-naḍ̂̀d fi şerhi Manțikị'l-tecrid, nşr. Muhsin Beydarfar (Kum: İntişârât-1 Beydar, 1430), 28.

12 Aristoteles, Organon, çev. H. Ragıp Atademir (Ankara: Milli Eğitim Basımevi, 1963), 1/33-34.

13 Mâcit, "Teşkîk", 567.

14 Aristoteles, Metafizik, çev. Ahmet Arslan (İstanbul: Sosyal Yayınları, 2014), 315-318 (VII.4 1030a 30-35). 
fertleri üzerine söylenirken; ikinci anlamda ise, mahiyet farklarıyla birlikte dünyevi ve uhrevi nefisleri karşılamak için söylenmiştir. ${ }^{15}$

Fârâbî, Kitâbü'l-cedel'de teşkîk kavramını kıyas konusu içerisinde şöyle tanımlamaktadır: "Teşkîk karşıt sonuç veren iki kıyasın birleştirilmesidir. Bu, yalnızca küçük öncülleri iştirak eden ve büyük öncülleri ise karşıt olan öncüller vasitasıyla gerçekleşir." ${ }^{16}$ Kitâbü'l-ibâre' de ise teşekkük kavramını "akla bir inancı ve karşıtını beraberce getiren şey" anlamında tanımlamıştır. ${ }^{17}$ Şu halde o, konumuz açısından doğrudan teşkîki kavramlardan bahsetmemiş ancak kelimenin tabiî anlamına işaret etmiştir. Konumuzla bağlantılı olarak onun mantığında teşkîk kavramına rastlanmamakla birlikte verdiği örneklerden teşkîke ulaşılmaktadır. Yani eş sesli (müşterek), dereceli anlamdaş (müşekkek) ve eş anlamlı (mütevâtı) isimler arasındaki farklara "manaları umum ve husus yönünden farklı olan isimler (mütefâdıl)" aracılığıyla ancak varılabilir. ${ }^{18}$

İbn Sînâ'ya gelince o, teşkîk konusunu mantık ilmine kazandırmış; bunun yanında metafizikte sınırlı bir teşkîk anlayışını kabul etmiştir. İbn Sînâ'ya göre eşit anlamlılık (tevâtu) yoluyla isimlendirmede isim, isimlendirilen şeylerde bütün yönlerden aynı anlama gelir. İsimlendirilenler hem anlam hem hak etme bakımından bir olup uygunluk-uygunsuzluk, önce-sonra, güçlü-zayıf olmak bakımlarından farklılaşmaz. İbn Sînâ eşit anlamlılık dışında olan kelimeleri üçlü bir tasnife tâbi tutmuştur: Birinci gruptakilerin anlamı bir ve aynı olup farklı yönlerden ayrışırlar. İkinci gruptakilerin anlamı bir ve aynı değil fakat benzerdir. Üçüncü gruptakilerin anlamı ise ne aynı ne de benzerdir. O, birinci gruptakileri müşekkek diye isimlendirir ve şöyle tanımlar: "Müşekkek, lafızdan anlaşılan anlam soyutlandığ 1 takdirde bir olan ama o lafızda ortak şeylerde bütün yönlerden bir ve benzer olmayandır." 19

İbn Sînâ' da müşekkek kavramların dört çeşit olduğu görülür: Birinci olarak mutlak müşekkek, kendisini önce-sonra, daha layık, daha güçlü ve daha zayıf olmada gösterir. Bu açıdan bazı varlıklar diğerlerinden daha önce, bir nesnedeki renk diğer bir nesnedeki renkten daha güçlü olabilir. İkincisi bir ilkeye (mebde) nispeti bakımından müşekkek olanlardır. Bunun örneği tıbbî kelimesidir. Tıbba dair olan her şey tıp kelimesinin müşekkekidir. Üçüncüsü bir gayeye nispeti bakımından müşekkek olanlardır. Buna örnek olarak sağlık

15 Fazlur Rahman, The Philosophy of Mullā Sadrā (New York: State University of New York Press, 1975), 34.

16 Fârâbî, “Kitâbü'l-cedel” el-Manțlkııyetü'l li'l-Fârâbî, thk. Muhammed Tâki Dânişpejûh (Kum: Mektebetü Âyetüllahü'l-Uzmâ el-Mar'aşî el-Necefî, 1408), 1/367.

17 Ca'fer Âli Yâsîn, el-Fârabî fi hudûdihi ve rusûmihi, (Beyrut: Âlemü'l-Kütüb, 1985), 150.

18 Mübahat Türker Küyel, Fârâbî'nin Peri Hermeneias Muhtasarı, (Ankara: Atatürk Kültür Merkezi Yayını, 1990), 79; Aliye Güler, Fârâb̂̂, İbn Sînâ ve Gazzâlî Mantı̆̆ında Dilbilim Kavramları (İstanbul: Marmara Üniversitesi, Sosyal Bilimler Enstitüsü, Yüksek Lisans Tezi, 2015), 90-94.

19 İbn Sînâ, Kategoriler, çev. Muhittin Macit (İstanbul: Litera Yayıncılık, 2014), 21-23. 
verilebilir. Sağlıklı olmak gayesiyle yapılanlar onun müşekkekleridir. Dördüncüsü ise iki ve üçüncü grubun birleşimidir. Yani bir ilkeye ve gayeye nispeti bakımından müşekkektir. Bunun örneği ise ilkeleri yönünden bütün mevcutların Tanrı'ya bağlı olması ve gayeleri açısından da O'na dönmeleri hasebiyle ilahî/Tanrısal olarak isimlendirilmeleridir. ${ }^{20}$

Mantık açısından varlık kavramının ifade ettiği anlam, üzerine söylendiğ $i$ her şeyde aynıdır fakat dış dünyadaki bireylerde bulunuşu farklı farklıdır. Varlık, örneğin, cevherde arazlardan ve bir kısım cevherlerde de diğer bir k1sım cevherlerden daha öncedir. Bu durum arazlar için de geçerlidir. Varlık daha layık ve uygun olup olmamak yoluyla da farklılaşır ki zatı dolayısıyla var olanlar varlığa diğerlerinden daha evladır. Güçlü ve zayıf olmak bakımından farklılaşmaya beyazın tonları veya ışı̆̆ın türleri ve şiddeti örnek olarak verilebilir. $^{21}$

İbn Sînâ'yla ilgili olarak son olarak şu söylenebilir ki o ve taraftarlarının küllî konusunda yaptıkları ayrıma göre küllî: eşit ve dereceli olmak üzere ikiye ayrılır. Eşit küllînin dış dünyadaki bütün bireylerine uygunluğu eşit seviyedir. Yani küllînin hiçbir bireyi küllînin içerdiği şeyi karşılamakta bir diğerinden öncelikli değildir. Bu anlamda Ali ile Mehmet'in insanlıkları eşittir. Bu eşitlik mantıkî bir eşitlik olup ontolojik ve ahlaki değildir. Dereceli küllîye gelince ona mensup fertlerin gerçeğe uygunlukları bütün bireylerinde eşit olmayıp en azından bazı bireyleri bir diğerine göre öncelik ve sonralığa sahiptir. $^{22}$

Görüldüğü üzere İbn Sînâ, mantık ilmine önemli bir katkı yaparak kavram çeşitleri içerisine müşekkek kavramları katmıştır. Buna göre bu kavramlar üzerine söylendikleri nesnelere aynı anlamda fakat dereceli olarak söylenmektedir. Bu söyleyişle nesnelerin farklı yönlerde dereceli sıralanışı dile getirilmektedir.

Sühreverdî’ye gelince, ona göre tümel anlamlar tamlık-noksanlık yönünden dereceli bir sıralanmaya sahipse bunlara "müşekkek" denir. Örneğin beyaz beyazlıkta dereceleri farklı olmakla birlikte fildişi ve kar için "o, beyazdır"

20 İbn Sînâ, Kategoriler, 22-23; Güler, Fârâb̂̂, İbn Sînâ ve Gazzâlî Mantığında Dilbilim Kavramları, 142-143.

21 İbn Sînâ, Kategoriler, 21-22.

22 Murtaza Mutahhari, Felsefe Dersleri 2, çev. Ahmet Çelik (İstanbul; İnsan Yayınları, 1999), 367368. Küllînin taşıdığı anlam bütün fertlerini eşit olarak karşılayan mütevâtı kavramlara "cisim" kavramı örnek verilebilir. O, bütün misdaklarına bir şekilde yüklenir. Cisimlik yönünden bir cismi diğerinden farklılaştıran bir unsur bulunmaz. Her cismi diğerlerinden ayırt ettiren özel ve belirli özellikleridir. Müşekkek olanda ise fert ve misdakları arasında tasdik edilmeleri yönünden farklılık vardır. bk. Muhammed Tâkî Misbâh Yezdî, el-Menhecü'l-cedî̀ fi ta'limi'l-felsefe, nşr. Muhammed Abdü'l-Münim el-Hakanî (Beyrut: Dârü't-Teârifi li'lMatbûât, 2008), 1/347-348. 
diye söylenir. ${ }^{23}$ Yine sıcaklık da örnek olarak verilebilir. Sıcaklık, kendisi olarak kalmakla birlikte sıcaklık derecesinde artış ve azalma göstermektedir. ${ }^{24}$ Yani sıcaklık bir mahiyet olarak tüm bireylerini kapsar. Çünkü azlık ve çokluk gibi niteliksel değişikler niteliğin mahiyetinde bir değişiklik gerektirmez. Ona göre Meşşâiller güçlü ve zayıf hakkında yanılmışlardır. Onlar hayvanlığı yönünden bütün hayvanları eşit olarak hayvan kabul ederler. Yine hayvanı, "nefsi olan, hisseden ve iradeyle hareket eden bir cisim" olarak tanımlarlar. Oysa bu tanıma göre, hayvanların aralarında derece ve mertebe yönünden farklı oldukları oldukça aşikârdır. ${ }^{25}$ Şu halde Sühreverdî’ye göre teşkîk mahiyetlerde gerçekleşmektedir.

Molla Sadrâ'ya göre Meşşâîler mantık bilimi açısından siyahın tonlarındaki farklılaşmayı onun fasıllarında/türlerinde farklılaşma olarak kabul ederken Sühreverdî ise siyahlık da teşkîki bir farklılaşmaya gitmiştir. Yani Sühreverdî’ye göre mahiyetlerde teşkîk geçerlidir ve bir siyahlık başka bir siyahlığa göre daha evla olabilir. ${ }^{26}$ Özetle Meşşâîler, dış dünyada bulunması açısından siyahın teşkîke tâbi olduğunu iddia etmişken İşrâkiler ise bu iddiayı reddetmiştir.

Sadrâ, Meşşâ̂lerin siyahlıktaki teşkîkin siyahın fasıllarında gerçekleştiğini söylediklerini ve buradaki fasıllardan maksadın onların dış dünyadaki varlığı olduğunu bildirir. Yoksa zihinsel anlamda fasıllar teşkîke tâbi değildir. Ona göre Sühreverdî, fasılları cinslerde gerçekliğe kavuşan arazlar olarak kabul eder. Dolayısıyla arazlar için söz konusu olan şeyler gerçekte cinslere aittir. ${ }^{27}$ Kendisi ise bir şeyin faslını varlığının bir yönü olarak değerlendirir. Bu görüşü kendisine ilham edilen çok değerli bir görüş olarak kabul eden Sadrâ, mahiyeti zihinsel taksimleri yönünden varlıktan ayrı bir şey olarak görse de ona göre son noktada mahiyet varlığa tâbidir. Yani mahiyetin dış dünyadaki hüküm ve eserleri olarak kabul edilebilecek neyi varsa varlığa aittir. Şu halde siyahlık faslı onun tanımından alınmış değil bizatihi dış dünyadaki varlığından alınmıştır. Bu durum cevher için de geçerlidir. Şu halde varlığın tanımı olmadığ 1 gibi faslın da tanımı yoktur. ${ }^{28}$ Başka bir ifadeyle siyahın tonlarında gözüktüğü gibi bir niteliğin farklı manaları ihtiva ettiğinin zannedilmesi yanlıştır. Doğrusu, siyahın tonlarını karşılayan manaların hepsinin varlığa ait

23 Sühreverdî, "el-Ḥikmetü'l-İşrâk" Mecmû'âtü mușannefâti Şeyḥi İşrâk, nşr. Henry Corbin (Tahran: Pijûhişgâh-1 Ulûm-i İnsâni ve Mutâla'ât-1 Ferhengi, 1373), 18.

24 Sühreverdî, Hikmetü'l-İşrak: İşrak Felsefesi, çev. Tahir Uluç (İstanbul: İz Yayıncllık, 2009), 99.

25 Sühreverdî, "Hikmetü'l-İşrâk", 87-88.

26 Molla Sadrâ, el-Hikmetü'l-müte'âliye fi esfâri'l-erba'a, 1/513.

27 Molla Sadrâ, "eş-Şevâhidü'r-rubûbiyye" Mecmû'a-yi resấil-i felsefí-yi Șadrü'l-müte'ellihîn, thk. Hamid Naci İsfehanî (Tahran: Bunyâd-i Hikmet-i İslâmi-yi Șadrâ, 1389), 1/406-407.

28 Molla Sadrâ, "eş-Şevâhidü'r-rubûbiyye", 1/406-407. 
farklı yönler olmasıdır. Bu yönler küllî anlamında değil; tam aksine şeyin tahakkuk etmesi anlamındadır. ${ }^{29}$

Sonuç olarak İbn Sînâ ve Molla Sadrâ'ya göre varlık kavramı mefhumu yönünden değil dış dünyadaki gerçekliği yönünden müşekkektir. Çünkü varlık, mefhumu yönünden bütün vücut mertebelerine eşit olarak söylenir. Işık da bunun gibidir. Güneş, ay, yıldız veya lambanın ışı̆̆ı mefhumları itibariyle aralarında üstünlük taşımazlar ancak muhtelif mertebelerde ve farklı derecelerde kendilerini gösterirler.

\section{Teşkîk Kavramının Felsefi Anlamı ve Varlık Örneği}

Başlangıçta ifade etmek gerekir ki mantıktaki teşkîk ile felsefedeki teşkîk arasında fark vardır. Mantıkta teşkîk, küllî anlamın fertleri üzerine söylenen mefhumunun doğrulanmasında farklılı̆̆ın olmasıdır. Felsefede ise varlığın basit olması, varlık-mahiyet ayrımı, zorunlu-mümkün, vahdette kesret kesrette vahdet gibi meselelerle alakalıdır. Felsefi teşkîk gerçekleşmedikçe mantıkta kavramlar teşkîk özelliğine sahip olamazlar. ${ }^{30}$

Teşkîk ıstılahta iki kısma ayrılır: özel manada teşkîk ve umumi manada teşkîk. Birinci teşkîk; cüzi tezahürlerinin birbirleriyle özdeş hale geldiği tek bir gerçekliğin aynı anda bu tezahürler arasındaki farklılığın sebebi olmasıyla elde edilir. Örneğin "iki" ile "iki bini" birleştiren özdeşlik ilkesi "sayı denilen hakikatin kendisi" olduğu gibi aralarındaki farklılık ilkesi yine bu sayısal hakikattir. Aynı şekilde güneş, ay, lamba ve ateş böceğinin ışığı aynı 1şık olmakla birlikte tahakkukları arasında farklılık söz konusudur. Farklı 1şıkları özdeş kılan ilke ile birbirinden ayıran ilke yine birdir. İkinci teşkîk türünde bir gerçekliğin tezahür biçimleri gerçekliği farklılaştırmaz. Örneğin Mehmet ve Ali, insanlığı çoğaltmaz. Ali, çiçek, at veya altının var olması varlık kavramını farklılaştırmaz. Teşkîkin bu ikili ayrımı önemlidir. Çünkü varlık "kavram olarak" teşkîkin ikinci türüne, varlığın gerçekliği/hakikati ise birinci türüne aittir. Bu açıdan vücut kavramı evrensel anlamda bütün varları ifade edebilirken hakikati açısından aralarındaki derece farkları dikkate alınarak söylenmelidir. ${ }^{31}$

Yukarıda ifade edilen ayrım akılda tutulmak kaydıyla ifade etmek gerekirse Eflâtun'un idealar doktrini tam bir idealizme evrilmediği müddetçe teşkîk fikrine paralel bir düşünce olarak değerlendirilebilir. Çünkü görünür âlemin varlık seviyesi ideal âlemin varlık seviyesinden daha az gerçek, daha zayıf ve daha noksandır. Aristoteles'e gelince, cevher kategorisinin asıl ve ger-

29 Molla Sadrâ, "eş-Şevâhidü'r-rubûbiyye", 1/389.

30 Abbas Ali Sebzevârî, “Tâliḳ” Nihâyetü'l-ḥikme (Kum: Müessesetü Neşri'l-İslâmî, 1434), 1/32.

31 Toshihiko İzutsu, İslam'da Varlık Düşüncesi, çev. İbrahim Kalın (İstanbul: İnsan Yayınları, 1995), 198-199. 
çek anlamda, diğer kategorilerin ise ikinci dereceden bir anlamda var olduklarını dile getirirken aslında o, teşkîk fikrini de nüve olarak ortaya koyar. Ayrıca o, töz için geçerli olan bu durumun öz/mahiyet için de geçerli olduğunu belirtir. ${ }^{32}$ Aristoteles' in "Varlığa dair şeyler ne eş sesli ne de eş anlamlıdır. Tam aksine ortak bir doğayla ilgili anlam dereceleridir." sözü onun teşkîke dair en açık sözüdür. Töz ve arazlar mevcutta birleştiğine göre mevcut ve mahiyetin dış dünyada birbirinden ayrılmadığı söylenebilir. ${ }^{33}$

Fârâbî'nin "mevcut" kavramı üzerindeki yoğun ilgisi dolayısıyla metafiziğin konusunun belirginleşmesinde önemli katkı sağladığı bilinmektedir. Bu meyanda o, mevcut kelimesini bütün kategoriler için kullanır. Kitabü'lhürûf ta bildirdiğine göre bütün cins ve türlere mevcut ismi tam eşitlikle (tevâtu) söylenir. ${ }^{34}$ Yani mevcudun isim olarak konulduğu nesneler arasında herhangi bir fark, öncelik-sonralık ve güçlülük-zayıflık yönünden dereceli bir sıralanma söz konusu değildir. $\mathrm{O}$, üstün cinslerin en üstünüdür. Mevcut, mastar anlamıyla kullanılması durumunda türemişliği ifade etmez aksine vücut anlamını ifade eder. Bu anlamıyla o, eş anlamlı olarak şey kavramına benzer. ${ }^{35}$ Mevcut her kategori için söylenir ve nefsin dişında bir mahiyete sahip olan ve işaret edilebilir her şeyi temsil eder. ${ }^{36}$ Fârâbî’nin bu yöndeki düşünceleri adı konmamış bir teşkîk fikrine yönelik olarak yorumlanabilir.

Yine Fârâbî, el-Medinetü'l-fâzıla' da felsefi anlamda teşkîkin menşei olabilecek ve kendisinden sonraki filozofları etkilediği düşünülen izahlarda bulunmuştur. Kitabın başında "Mevcutların İlki ve En Önce Olanı Hakkında” başlığı altında yazdıkları okununca İlk Mevcudun varlığının teşkîki bir niteliğe sahip olduğu düşünülmektedir. Ancak İlk Mevcudun bir olduğunun anlatıldığı ikinci başlığın içeriği, okuyucunun bu düşünceden uzaklaşmasına neden olmaktadır. Nasıl yorumlanırsa yorumlansın onun "Zira bu ikisi arasında bir farklılık olmuş olsaydı sayesinde farklılaştıkları şey, kendisinde ortaklaştıkları şeyden başka olurdu." 37 cümlesi teşkîkin ana karakterini ortaya koyması açısından önemlidir. Bu cümleden anlaşılan Fârâbî'nin varlığı teşkîki bir kavram olarak görmediğidir. Eğer görmüş olsaydı; cümleyi “Varlıkta farklılaştıkları şey, kendisinde ortaklaştıkları şeyle aynı olurdu." şeklinde ifade etmesi gerekirdi. ${ }^{38}$ Fârâbî, yukarıda belirttiğimiz gibi ilk başlık altında dile getirdikleriyle çelişmemek ve İlk Mevcudun varlığının birliğini ortaya koymak için

32 Aristoteles, Metafizik, 252-253 (V.7 1017a 25-35); İbn Rüşd, Metafizik Büyük Şerhi, çev. Muhittin Macit (İstanbul: Litera Yayıncilık, 2016), 1/876.

33 Aristoteles, Metafizik, 315-318 (VII.4 1030a 30-35).

34 Fârâbî, Kitâbü'l-ḥurûf (Harfler Kitabl), çev. Ömer Türker (İstanbul: Litera Yayıncllık, 2018),118.

35 İrfan Görkaş, “Farabi Metafiziğinde Varlık (El-Mevcûd) Terimi ve Eklentileri”, Bozok Üniversitesi Illahiyat Fakültesi Dergisi 6/11 (Haziran 2017), 73-76.

36 Görkaş, "Farabi Metafiziğinde Varlık (El-Mevcûd) Terimi ve Eklentileri”, 76.

37 Fârâbî, el-Medînetü'l-Fâzıla, çev. Yaşar Aydınlı (İstanbul: Litera Yayıncılık, 2018), 44-48.

$38 \mathrm{Ki} \mathrm{bu}$ formülasyon sonra ki dönemlerde ifade edilegelmiştir. 
devamında, İlk Mevcuttan sonraki ilk malulün İlk Mevcuttan varlık yönünden değil mahiyeti/imkânı yönünden farklılaştığını dile getirmektedir.

İbn Sînâ ise Şifâ'nın Metafizik kitabında teşkîki güçlü-zayıf, daha az-daha çok olması açısından kabul etmezken önce-sonra, istiğna-ihtiyaç ve zorunluluk-imkân açısından kabul eder. Teşkîk açıklamasını illet ve malul üzerinden yapmasından anlaşılacağı üzere o, illet karşısında malulün varlığına bağımsızlık ve ayrıklık vasfı vermez. ${ }^{39}$ Buna rağmen onun güçlülük-zayıflık ve daha az-daha çok olma noktasında teşkîke olumlu bakmaması hem tutarlılık hem de genel sistemi açısından sorgulanmaya açıktır. Onun güçlü-zayıf, daha azdaha çok ayrımlarında teşkîki kabul etmemesi cevherde hareket ve değişimi kabul etmemesinden kaynaklanmış görünmektedir. Ayrıca bu kayıtlı kabul Vâcip Varlığın ontolojik statüsüne karşı duyulan hassasiyetin bir sonucu gibidir. Ve yine âlemle irtibatı yönünden diğer üçlüde görülen keskin ayrımın ilk iki ayrımda sağlanamadığı aşikârdır.

İbn Sînâ'nın, aynı tavrını Danışnâmei Âlâı̂'de sürdürdüğünü görmekteyiz. Ona göre kategorilerin her birine aynı anlamda varlık ismini vermek doğru değildir. Şöyle ki nitelik ve niceliğin varlığı aynı ise "nitelik vardır" demek "nitelik niteliktir" anlamına gelir. Bu ise varlığın analitik bir yüklem olduğu anlamına gelir. Hâlbuki varlık yüklem olarak sentetiktir. Ancak varlığın sentetik olma vasfı dış dünyadaki bulunması durumunda söz konusudur. Çünkü mahiyetler zihinde kaldıkları müddetçe varlık yüklemiyle yeni bir şey elde etmezler. Zaten nitelik ve nicelik dediğimiz zaman zihinde bunların farklı özellikleri belirginleşmiş olur. ${ }^{40}$ Burada kast edilen nitelik ve niceliksel varoluşlarının teşkîke tâbi olduğudur. Yani zihinde farklılaşmaları için dış dünyada farklılaşmaları gerekir. Şu halde farklılaşmayı sağlayan unsur aynı zamanda birleşmeyi de sağlamaktadır. İşte teşkîkin ana fikri de budur.

İbn Sînâ, dış dünyadaki müşahhas varlıklarının birbirinden ayrı gibi durmasının ortak bir cevherde toplanmalarına ve varlıklarının da genel bir varlık altında toplanmasına engel teşkil etmediğini söyler. Lakin bu söylevde üç şeye dikkat edilmelidir: Birincisi dış dünyadaki varlık bir cins değildir. İkincisi kategoriler varlıkta bir fazlalaşmayı gerektirmez. Üçüncüsü kategorilerin mevcut olması eş anlamlılıkla değildir. Kısacası varlık; ne cins ne fasıl/ayrım ve ne de bu on kategoriden herhangi bir şey değildir. ${ }^{41}$ Kanaatimizce onun bu varlık anlayışı, felsefeye dair en önemli görüşüdür ve varlığın müşekkek bir kavram olarak kabul edilmesini gerektirir. Kendisinden sonra bu görüş, güçlü bir şekilde İslâm filozoflarını etkilemiştir.

39 İbn Sînâ, Metafizik, çev. Ekrem Demirli - Ömer Türker (İstanbul: Litera Yayıncılık, 2017), 246.

40 İbn Sînâ, Dânişnâme-i Alâî, çev. Murat Demirkol ( İstanbul: Türkiye Yazma Eserler Kurumu Başkanlığı Yayınları, 2013), 174.

41 İbn Sînâ, Dânişnâme-i Alầ, 174-176. 
Son olarak İbn Sînâ, Ta'lîkât'ta iki siyah şey arasındaki derece farkının onların varlıkları üzerinde vâki olduğunu söyler. Çünkü mutlak manada siyahlık birdir. Siyahtaki çokluk ve azlık muayyen bir siyaha, gayeye yakınlığı ve uzaklığına göre arız olur. ${ }^{42}$ Özetle İbn Sînâ'nın varlığın teşkîki fikrine ulaşması hem zorunlu-mümkün hem de varlık-mahiyet ayrımı açısından önemlidir. Ancak onun teşkîk fikrini son noktaya taşıma gayreti içerisinde olmad1ğını ve bu fikrin geliştirdiği diğer fikirlerin gölgesinde kaldığını söyleyebiliriz. Bununla birlikte İbn Sînâ; varlığın teşkîk niteliğine sahip olduğunu söyleyerek "nasıl oluyor da basit varlığın bir olmasına rağmen aynı zamanda çokluğun kaynağ1 olduğu sorusuna" büyük ölçüde çözüm getirmiştir, oluyor. Başka bir ifadeyle o, teşkîk fikriyle Tanrı ile âlem arasında ontolojik anlamda ortaya çıkacak aynılık ve gayrılık sorununun halledilmesini hedeflemiştir. Ayrıca onun bu önemli çıkışı, İbnü'l-Arabî (öl. 638/1240) ve Molla Sadrâ gibi sistem kurucu düşünürleri etkilemiş ve bu iki düşünür tarafından varlığın birliği ve asaleti görüşünün gelişmesine kaynaklık etmiştir, denilebilir.

Nasîrüddin Tûsî'nin konuyla ilgili olarak İbn Sînâ'yı takip ettiği görülür. O, varlığın teşkîki dolayısıyla vacip ve mümkün varlığın gereklerinin bir olmasının zorunlu olmadığını vurgular. ${ }^{43}$ Tûsî; İbn Sînâ'nın el-İşârat vet-tenbihât adlı eserine yazdığı şerhte, Fahreddin er-Râzî’nin (öl. 606/1210) vücudun mevcudat üzerine lafzi iştirak ile söylendiğini zannettiğinden bahseder. erRâzî bu zannı dolayısıyla vücudun her şeye "eşit olarak" söylenen bir şey olduğu sonucuna ulaşmıştır. $\mathrm{O}$, buradan Vacip Varlık ile mümkün varlığın eşit olduğunu hatta mümkünlerin varlıklarının mahiyetlerine arız olmasından hareketle Vacip Varlık'ın varlığının da mahiyetine arız olduğunu düşünmüştür. ${ }^{44} \mathrm{Bu}$ hata vücudun teşkîki yapısını anlayamamaktan kaynaklanmıştır. Tûsî'ye göre teşkîk, eş sesli (müşterek) anlamında kullanılmaz. Örneğin Arapçadaki ayn/göz kelimesi aynı anlamda farklı nesnelere isim olarak verilir. Veya insan kelimesi, üzerine isim olarak verilen fertleri eşit olarak karşılar. Ancak teşkîk böyle değildir. Teşkîkte durum zihinsel isimlendirme üzerinden değil dış dünyadaki özdeşlik üzerinden ilerler. Fakat bu özdeşlik miktar ve miktar sahibi cisimde vaki olduğu gibi ya öncelik ve sonralık farklılığı içerir; ya da evvel olmaklık ve bunun yokluğundaki dereceli birliktelikte kendisini gösterir. Bununla birlikte varlık kendindeki bütün farklılaşmalarıyla birlikte

42 İbn Sînâ, et-Ta'lîkât, nşr. Abdurraḥman Bedevi (Beyrut: Dâru'l-İslâmiyye, 1972), 44.

43 Sadreddin Konevî, Yazışmalar, çev. Ekrem Demirli (İstanbul: İz Yayıncılık, 2002), 106.

44 İbn Sînâ, el-Işârât ve'n-tenbîhâat mea şerḥi Nașîruddin et-Ṭ̂sî, nşr. Süleyman Dünya (Kahire, Dâru'l-Meârif, 1985), 3/30. 
yine kendisidir. Sonuç olarak farklı şeyler üzerine aralarında eşitlik olmaksızın söylenen bir mananın bu şeylerin mahiyeti veya onun bir parçası olması imkânsızdır. Çünkü mahiyet ve mahiyeti oluşturan parçalar farklılaşmaz. ${ }^{45}$

Sühreverdî’ye gelince o, varlığı dış dünyada gerçekliği olmayan zihinsel bir kavram olarak kabul etmektedir. Şöyle ki varlığın dış dünyada kendisi olarak bir karşılığı ya vardır ya yoktur. Varsa her mevcuda ait varlığın varlığından önce olması gerekir. Bu ise saçmadır. Ya da yoktur ki ona göre doğrusu da budur. Yani dış dünyada özdeşliği cihetiyle varlık diye bir şey gösterilemez. ${ }^{46}$ Öyleyse Sühreverdî’ye göre varlık bütün mevcutlara eşit olarak söylenen zihni bir mefhumdur. Doğal olarak onun dış dünyada teşkîki niteliğinden bahsedemeyiz.

Sühreverdî nur kavramı için doğrudan teşkîk kavramını kullanmaz. Ancak hükümran ve yönetici gibi soyut nurların cisimler gibi miktarı yoktur. Bu yüzden onlar bileşik olmayan yapıları itibariyle aynı hakikati paylaşırlar. Ancak aralarında kemal ve noksanlık yönünden farklılık vardır. Bu açıdan hakikatinde hiçbir noksanlık bulunmayan nurdan başlamak üzere nurların dikey boyutta sıralanışı söz konusudur. Bu sıralanış başkasında heyet olan arazi 1şıklarda son bulur. Böylece sıra düzenli 1şıklar âlemi vücut bulur. ${ }^{47}$ Özetle Sühreverdî varlık kavramına bedel olarak kullandığı nur için ve varlık karşısında asalet sahibi olarak kabul ettiği mahiyetler için teşkîki benimser. Ayrıca huzurî bilgi nurun teşkîki yapısını bilmenin mümkün olduğu bilgi çeşididir. Çünkü zihin apriori bilgilerinde yanılgıya düşmese de yanlış akıl yürütme sonucunda yanılabilmektedir. Ayrıca varlığın teşkîki niteliği dış dünya açısından önce huzurî bilginin gerçekliğini onayladı̆̆ı bir şey olmalıdır.

İbnü'l-Arabî ve öğrencisi Sadreddin Konevî (ö. 673/1274) gibi mutasavvıflar varlığın mertebeli varoluşunu savunmuşlardır. ${ }^{48}$ Bunun yanında onlar varlığın çoklu birliği veya varlığın tekli çokluğunu zihinsel formülasyonundan ziyade diş dünyadaki gerçekliği yönünden tecrübe ettiklerini iddia etmektedir. Bu tecrübe vahdet-i vücut ve bunun kozmolojik yansıması olan "Varlık bir olmakla birlikte mertebeli bir varoluşa sahiptir." şeklindeki varlık mertebeleri fikri teşkîkin başka bir ifade biçimi olarak değerlendirilebilir.

İbn Sînâ, el-Işârât ve'n-tenbîhât mea şerḥi Nașîruddin et-Ṭ̂ûî, 3/31. Ali Kuşçu Şerhü Tecrîdi'l'akā'id kitabında varlığın teşkîki niteliğine dikkat çekerek Tûsî'nin İşârât'ın şerhinde dile getirdiği görüşünü tekrar eder. Buna göre illetin varlığı malulün varlığından, cevherin varlığı da arazın varlığından öncedir. Bir mahalle yerleşen arazların varlığı arasında ise güçlülük ve zafiyet farkı söz konusudur. Ali Kuşçu, Şerḥü Tecrîdi'l-'akā’id, nşr. Muhammed Hüseyin Zirâî Rızâyî (Kum: İntişârât-1 Râid, 1393), 1/181.

46 Sühreverdî, Hikmetü'l-İşâk , 64-65.

47 Sühreverdî, Hikmetü'l-İşrâk, 167. Bk. Henry Corbin, İslâm Felsefesi Tarihi (Başlangıcından İbn Rüşd'ün Ölümüne), çev. Hüseyin Hatemi (İstanbul: İletişim Yayıncılık, 1994), 366-371; Ahmet Kamil Cihan, "Sühreverdî'nin Nur ve İnsan Düşüncesi", Doğu'dan Batı'ya Düşüncenin Serüveni, ed. Eyüp Bekiryazıcı (İstanbul: İnsan Yayınları, 2015), 7/979.

48 İbnü'l-Arabî, Fusûsü'l-Hikem, çev. Nuri Gençosman (İstanbul: MEB Yayınları, 1992), 94. 
Teşkîk konusunun belirginleşmesinde Molla Sadrâ'nın özel bir yeri vardır. Ona göre "varlığın teşkîki" düşüncesi tevhit kapısının anahtarıdır. Şöyle ki, teşkîk fikri; varlığın bütün mevcutlara aynı anlamda yüklenmesi sayesinde birliği ve dereceli varoluşu ifade etmesi anlamında da farklılığı ortaya koyabilecek güçtedir. İkincisine göre mevcutların en mükemmeli ve güçlüsü, varlığı salt gerçeklik olan Tanrı'dır. Onun varlığına herhangi bir mahiyet ilişemez. Tanrı, varlığının şiddeti yüzünden gözlerden gizlenir. Onu aşikâr kılan da, zihin ve kalplerden gizlemesine vesile olan da onun bu özelliğidir. ${ }^{49}$ Öyleyse Tanrı'nın birliği iki yönde yorumlanabilir. Birincisine göre Tanrı, varlı̆̆ı bütün mevcudatı var kılması yönünden biricik varlıktır. İkincisine göre Tanrı'nın varlığı basitlik, şiddet, kemal ve tamlık yönünden biriciktir.

Varlık, bütün birey ve hususiyetleriyle dış dünyada vaki olan basit bir hakikat $^{50}$ olduğundan şahıs ve hususiyetleri arasında güçlülük-zayıflık, azlıkçokluk, öncelik-sonralık ve zenginlik- yoksunluk yönünden farklar vardır. Varlık kendisinde; küllî veya küllî arazî ve tabiî küllî olmadı̆̆ı gibi cins ve tür altında gerçekleşen cüzi de değildir. Bununla birlikte varlık bütün mevcutları kuşatır. Onun kuşatması, küllînin cüzileri kuşatması gibi değildir. Varlığın mümkünlerin heykelleri üzerine yayılması ancak ilimde derinleşenlerin bilebileceği bir yönden gerçekleşir. ${ }^{51}$

Sadrâ'ya göre varlık bir olmakla birlikte farklı mertebe, eser, tavır ve gereklere sahiptir. Hal böyleyken bu sayılanlar küllî manalar olmaları cihetiyle şiddet ve zayıflık kabul etmezler. Yani mahiyetlerin teşkîki söz konusu değildir. Varlık, mahiyet karşısında asalet sahibi olduğundan yetkinlik ve noksanlık yönünden farklılaşmaktadır. Şu halde bütün ayanlarda taayyün eden varlıktır. Hatta varlık, önce ve sonra olmanın ta kendisidir. Nur kavramı da varlık kavramı gibi, ifade ettiği mana yönünden farklılaşmamakta yalnızca dış dünyadaki gerçekliği yönünden derecelenip farklılaşmaktadır. ${ }^{52}$

Sadrâ "cevherî hareket prensibi" dolayısıyla değişimi mahiyetlerde değil cevher ve cevhere bağlı olarak arazlarda geçerli kabul eder. Buna göre siyahın siyahlığı kalıcı bir siyahlığın üzerine başka bir siyahlığın eklenmesiyle artmaz. Bilakis üzerinde siyahın var olduğu konunun kalıcılığıyla beraber konuda hâsıl olan siyahın zatının yok olması ve peşi sıra ondan daha güçlü

49 Molla Sadrâ, Arşa Ait Hikmetler, çev. Fevzi Yiğit (İstanbul: Önsöz Yayıncılık, 2019), 27-28.

50 "Şu halde varlık, zatında zatı ile şahsileşmiş, cinsi ve faslı olmayan basit bir şeydir. O aynı zamanda bir şeyin cinsi, faslı, türü, umumî arazı ve hassası değildir. Zihnen soyutlanan mâna gibi varlığın da mevcutların arazı olduğuna dair söylenen şeye gelince bu şey, varlığın hakikati değildir... Varlık basit ve tek bir hakikattir." Molla Sadrâ, Kitâbü'l-meşâir (Metafiziğge Giriş), çev. A. Kamil Cihan vd., (İstanbul: Endülüs Yayınları, 2019), 38-40.

51 Molla Sadrâ, eş-Şevâhidü'r-rubûbiyye, 362.

52 Molla Sadrâ, eş-Şevâhidü'r-rubûbiyye, 387-388; Molla Sadrâ, Şerḥu ve ta'lîkatü Şadrü'l-müte'ellihîn İlâhiyyâti'ş-Şifâ', nşr. Necefkulu Habibi (Tahran: Bunyâd-i Hikmet-i İslâmi-yi Șadrâ, 1382), 1/117. 
başka bir siyahın hâsıl olmasıyla gerçekleşir. Yani mevzuda mahiyetsel bir değişiklik değil varlıksal bir değişiklik gerçekleşir. İşte bu cevherdeki harekete bağlı olarak arazda da gerçekleşmekte olan harekettir. ${ }^{53}$

Meşşâiler teşkîki, mevcutların nitelikleriyle sınırlandırmıştı. Hâlbuki Sadrâ'ya göre nitelikler, mevcutların varlıklarının farklı derecelerine ait yönlerinden başka bir şey değildir. ${ }^{44}$ Sadrâ, "varlıkta esas olan kemal ve noksanlık" ilkesini Sühreverdî'den devralmıştır. Sadrâ, bu ilkede iki temel değişikliğe gitmiştir. Birincisi, teşkîk olarak adlandırılan bu ilkeyi öze/mahiyete değil, varlığa uygulamıştır. İkincisi ise mahiyetler tek anlamlı olmasına rağmen, varoluşu eş zamanlı veya belirsiz olarak kabul etmiştir. ${ }^{55}$ Anlaşılan filozoflar varlık ve mahiyet ikilisinden hangisinin asaletini savunmuşsa onun teşkîke tâbi olduğunu düşünmüştür.

Mevcutların akletmesi ve akledilmesi varlığın teşkîki yapısına göre derecelenir. Bir mevcut ne kadar var ise o kadar bilir ve bilinir. Yani mevcutlar yoğunluk-azalma, güçlülük-zayıflık, öncelik-sonralık ve yetkinlik-noksanlık gibi yönlerde derecesi arttıkça bilgisi ve bilinmesi artmaktadır. Şu halde en çok ve en iyi bilen ve bilinen varlık Tanrı olmak durumundadır. ${ }^{56}$

Sadrâ'nın "el-hikmetü'l-müteâliye/aşkın hikmet" felsefesini takip eden Hâdî-i Sebzevârî (öl. 1289/1872) "varlığın hakikatinin birliğine” dair bir konu başlığı altında Pehlevî Hakîmlerinin varlığın hakiki bir zat sahibi olmasının manasının onun varoluş mertebelerini dolduran genel teşkîk sahibi olduğunu; bütün tavır, hal ve durumları ihtiva ettiğini belirtir. Varlık; zenginlikfakirlik, şiddet ve zayıflık, öncelik ve sonralık sahibi olarak en çok nur ile karŞılanabilir. ${ }^{57}$ Varlık ve nur mertebeler sahibi müşekkek birer hakikattir. Nurun fiziksel karşılığı olan ışığın şiddeti ve çeşitleri onun 1şık olmak hakikatinden tereddüt etmemizi gerektirmemekle beraber ışı̆̆ın dereceli yapısını da inkâr edemeyiz. Işıktan hareketle nurun basit bir gerçeklik olması dolayısıyla bir; aynı zamanda çok olduğunu söyleyebiliriz. Fârâbî'nin eksik formüle ettiği gibi "nuru dereceli olarak çoğaltıp farklılaştıran şey ile onu bir kılan şey aynıdır." Başka bir tabirle varlığın mertebeleri arasındaki herhangi bir mertebenin

53 Molla Sadrâ, el-Hikmetü'l-müte'âliye fî esfâri'l-erba'a, 1/504.

54 Molla Sadrâ, eş-Şevâhidü'r-rubûbiyye, 389.

55 Fazlur Rahman, The Philosophy of Mullā Sadrā, 35.

56 İbrahim Kalın, Varlık ve İdrak, Molla Sadrâ'nın Bilgi Tasavvuru, çev. Nurullah Koltaş (İstanbul: Klasik Yayınları, 2013), 103.

57 Hâdî-i Sebzevârî, Şerḥü'l-Manzûme, nşr. Cevâd Âmulî (İran: Neşrinâb, 1369), 2/105. Sebzevarî bu kitabın birinci cildinde mantığı işlerken teşkîke değinir. Ona göre önümüzdeki her bir kar tanesi veya 1şıklardan her birisi kar tanesi ve 1şık dememiz açısından yani küllî mefhumları cihetinden farklılık göstermezler. Farklılık ancak bu şeylerin varlıklarında gerçekleşir. Sebzevârî, sayı ve 1şık gibi bazı küllîlerin kendisi içerisinde teşkîk ihtiva ettiğini de belirtir. 
diğerinden ayrılması, birleşmenin kendisiyle gerçekleştiği basit zatın kendisidir. Hâsılı nur veya varlık şiddet-zayıflık, önce-sonra ve üstünlük-alçaklık yönlerinden mertebeler sahibidir. ${ }^{58}$

Şiddet ve zayıflıkla farklılaşmanın gerçekleştiği yer olmasından dolayı varlık mertebeleri arasında mutlak ve izafi ilişkisi vardır. Varlığın zayıf bir mertebesi yetkinlik sahibi güçlü bir mertebesinin taşıdıklarını içermez. Bu aynı zamanda daha aşağıda olanın daha sınırlanmış olduğu anlamına gelir. Yani her bir mertebe yukarısındaki mertebeye göre sınırlıdır. Dikey yönde en yukarıda mutlak ve sonsuz olan vardır. Tersi yönde ise kemal ve fiili olmanın en zayıf noktasında madde yer alır. Varlığın aşağı ve yukarı doğru hareketinde sınırların artması dolayısıyla varlık daralır, mahiyet çoğalır. Tersi yönde varoluş yükseldikçe en yüksek mertebeye ulaşana kadar sınırlar azalır; varlık genişler ve mahiyet azalır. ${ }^{59}$

Teşkîk; herhangi bir küllî, çeşitli derece ve mertebelerde cüzlerine hamledildiğinde yahut tek bir gerçeklik bir grup nesnede fakat farklı derecelerde tahakkuk ettiğinde meydana gelir. ${ }^{60}$ Varlık teşkîki bir kavram olup buna bağlı olarak geliştirilen düşünceler, vücudun asaleti fikri üzerine inşa olunur. ${ }^{61} \mathrm{Zi}$ hin varlığın dış dünyadaki hakikatini olduğu gibi kavranmakta zorlanmaktadır. Belki de sadece metafizik sezgi ya da "aydınlatıcı huzur" (huzur-u işrâkî) bu güçlüğü giderebilir. ${ }^{62}$ Mutlak ile mümkün arasında hakikat/gerçeklik farkı değil seviye ve mertebe farkı vardır. Mutlak varlıkta varlık daha yoğun ve önce, mümkün varlıklarda ise daha zayıf ve sonradır. Keza vücudun maddi olmayan bir varlıktaki gerçekliği maddi bir varlıktaki gerçekliğinden daha güçlüdür. ${ }^{63}$

İzutsu varlığın kesafet-letafet, kemal-noksanlık ve öncelik-sonralık vb. açısından farklılıklarını onun zati kipleri olarak değerlendirir. Çünkü varlık âleminde varlık dışında bir gerçeklikten bahsedilemez. Varlığın sonsuz sayıdaki zati kipleri bazı ana mertebe ve derecelerle taksim edilmiştir. İşte bu taksimler ve buna bağlı olarak mevcutların isimlendirilmesi zihinsel açıdan mahiyetleri karşılarken ontolojik açıdan varlığın teşkîki niteliğini karşılar. ${ }^{64}$ Nihayetinde varlığın her şeyi kuşatması zihinsel seviyede genel ve tümel sayesindeyken

58 Muhammed Hüseyin Tabâtabâî, Nihâyetü'l-hikme, nşr. Şeyh Abbas Ali Sebzevârî (Kum: Müessesetü Neşri'l-İslâmî, 1434), 1/35.

59 Tabâtabâî, Nihâyetü'l-hikme, 36-37. Dereceli oluş ne mahiyetlerin zatındadır ne de ilineksel olgulardadır. Aksine varlığın kendisindedir. Bk. Mutahharî, Felsefe Dersleri 2, 372.

60 İzutsu, İslam'da Varlık Düşüncesi, 197-198.

61 İzutsu, İslam'da Varlık Düşüncesi, 158.

62 İzutsu, İslam'da Varlık Düşüncesi, 186. İzutsu, Sebzevârî'nin felsefî görüşleri üzerine yazdığı eserinde Pehlevî filozofların Mutlak ile mümkün varlık seviyesi arasında "hakikat farkı" gözettiklerini bildirir.

63 İzutsu, İslam'da Varlık Düşüncesi, 198.

64 İzutsu, İslam'da Varlık Düşüncesi, 199. 
dış dünyada ise ne bir genel ne tümel bir kuşatıcılık ve ne de nesnel bir kuşatma sayesindedir. Varlığın hakikati bir fakat çoktur; çok ama birdir. Buna en iyi örnek olarak nefes ve onun ürünü olan harfler verilebilir. ${ }^{65}$

Teşkîk, "felsefi anlamda varlığın sistematik olarak belirsiz olması" şeklinde tanımlanmıştır. Bu terkipte "sistematik" kelimesi varlık mertebelerini, belirsiz olması ise bütün açısından varlığın her şeye dönüşebilmesini ifade ediyor, gibidir. Başka bir ifadeyle varlık açılım ve zuhurun nedeni olup değişik aşamaları gerçekleştirmekte ve varoluş seviyesine ulaştığında ise sürekli hareket halinde kendini gerçekleştirmektedir. Bu hareket; varlığın genel, müphem ve yaygın seviyelerinden daha somut, bileşik veya unsuri formlarına doğru ilerlemesi anlamındadır. Bu hareket dolayısıyla ortaya çıkan her mevcut suret ve madde gibi davranır. Yani ortaya çıkan her cisim bir sonraki form tarafından yutulur. Daha mükemmele doğru ilerleyen bu hareket tek yönlü olup geriye sarılamaz. Burada mahiyetler varlıkla fonksiyonel olarak ilişkili durumları ifade eder. Ters orantılı olarak mahiyeti artıp varlığı güçsüzleşen mevcutlar aşağı doğru ilerlerler. Varoluş ölçeğinin en alt kısmına ulaşılınca aslında neredeyse var olmayan ilk maddeye ulaşılmış olur. İlk madde, "yalnızca var olma potansiyeli" olarak tanımlandığından sanki bir kavram/öz konumundadır. Bu skalanın en yüksek noktasında; mutlak varlık sahibi, özü olmayan ve bu yüzden hiçbir şekilde kavramsal düşünceye elverişli olmayan Salt Varlık vardır. Sonuçta "Varlık sistematik olarak belirsizdir." önermesi şu üç manaya gelir: Birincisi varlık tüm mevcudatta temel olarak aynı şeydir. Böyle olmasaydı her şeydeki varlık anlamı farklı olurdu. Bu durumda sistematik belirsizlik ve benzerlik kaybolur yerine varlığın farklılığı gelirdi. ${ }^{66}$

İkincisi her ne kadar varlık aynı olsa da bireyleri arasında oluşturduğu farklılıklar ile onları biricik kılar. Yani varlık herhangi bir soğan gibi hepsi birbirinin aynı olan fertlerden oluşan bir birlik değildir. Aksine varlık bir ailenin fertleri gibidir. Birbirlerine benzeseler de her biri biricik ve farklidir. Üçüncüsü varlıktaki cevheri hareket dolayısıyla alt formlar üst formlar tarafından içerilir. ${ }^{67}$

Varlık kavramının zihinsel, tümel ve İzutsu'nun ayrımında ifade edilen ikinci/kavramsal boyutuyla analitik bir yüklemdir. Sühreverdî'nin çıkış yeri de burasıdır. Bu anlamda varlık mahiyetsiz karakteriyle bilinemez bir zihinsel soyutlama olarak karşımızda durmaktadır. Bu anlamda Tanrı ile âlem arasında ontolojik bir bağlantı kurmak söz konusu gözükmemektedir. Ancak hakikati ve gerçekliği yönünden varlık, aralarında derece farkları olmakla birlikte bütün mevcutlara sentetik anlamda söylenir. Bu açıdan varlık tek öznedir, "en basit" olandır ve her şeydir. İşte bu yönüyle varlık teşkîki bir yapıya

65 İzutsu, İslam'da Varlık Düşüncesi, 202-203.

66 Fazlur Rahman, The Philosophy of Mullā Sadrā, 35-36.

67 Fazlur Rahman, The Philosophy of Mullā Sadrā, 37. 
sahiptir ve bunun bilgisi ancak huzur ve keşif sayesinde tam olarak elde edilebilir.

\section{Sonuç}

İnsanın varlık bilgisi çift yönlüdür. Şöyle ki insan zihni var olması yönünden birlik fikrine apriori olarak sahip olmakla birlikte aynı zamanda mahiyeti gereği idrak eylemini gerçekleştirebilmek için mevcutları ontolojik farklılık temelinde algılamak durumundadır. Başka bir ifadeyle zihin, özne-nesne ve bilahare Tanrı-âlem ayrımına gitmek durumundadır. Kendisinin sebep olduğu bu durumdan kurtulabilmek için konuyla ilgili olarak zihnin varlığın teşkîki niteliğini keşfetmesi gerekir. Bu keşfin gerçekleşememesi durumunda zihin, Aristoteles örneğinde olduğu gibi- Tanrı ile evren arasında ontolojik aykırılık ve kopuklukların gerçek olduğu sanısına kapılır. Bu sebeple İbn Sînâ ve Molla Sadrâ'nın mevcutların birliği ve çokluğu probleminin çözümü için vacipmümkün ve varlık-mahiyet ayrımına başvurdukları görülmektedir.

Varlık ve mahiyet ayrımında hangisinin diğerine dayanak ve asıl olduğu yönündeki karar, filozofların teşkîk konusundaki tavırlarını belirlemiştir. Varlık-mahiyet ayrımı, bir bakıma teşkîk fikrine karşılık gelmektedir. Çünkü bir mevcudun mahiyeti ne kadar artarsa varlığının gücü, yetkinliği ve tamlığı da o oranda azalmaktadır. Ancak mahiyet fikrinin doğru anlaşılmaması durumunda birçok hatalı görüşün ortaya çıkması söz konusudur. Bunlardan en bilineni mahiyetin varlık karşısında asalet sahibi olmasıdır. Bu durumda varlık, mevcutlar üzerine tevâtu ile söylenen bir isim durumuna düşmektedir. Ve yine varlık-mahiyet ayrımı Tanrı karşısında etkisini yitirmektedir. Çünkü Tanrı'nın mahiyetinden bahsetmek mümkün görünmemektedir. Şu halde teşkîk fikrine göre bu fikrin bazı yönlerden daha güçsüz olduğu söylenebilir.

Zorunlu-mümkün ayrımı ise bir açıdan varlık-mahiyet ayrımından daha güçlü bir izah biçimi olarak görülebilir. Çünkü zorunlu karşısında mümküne kendinde varlık fırsatı tanınmamaktadır. Bununla birlikte vehim, mümküne zorunludan kopuk bir mevcudiyet durumu vermekten kendisini alamamaktadır. Hatta vehme kapılan kimi düşünürlere göre mümkün varlık bulduktan sonra zorunlu olana artık ihtiyaç duymamaktadır. Bu durumda birlik fikrinin sağlanması güçleşmektedir. Hâlbuki teşkîk fikrinde varlık, bir olmakla birlikte, kendinde güçlülük-zayıflık gibi yönlerden farklılaşmaktadır. Burada önemli olan bu farklılaşmanın varlık dişında başka bir şeyde gerçekleşmemesidir. Yani teşkîk fikri "birlikte çokluk, çoklukta birlik" fikrinin bir tür izahı olarak ortaya çıkmaktadır.

Varlığın teşkîki niteliği varlığın basit olduğu fikrine dayanır. Eğer böyle olmasaydı varlık bileşenlerine ayrılacak ve her mevcutta farklı bir şey olarak karşımıza çıkacaktı. Yine varlığın güçlülük-zayıflık, kemal-noksanlık, önce- 
lik-sonralık, ihtiyaçsızlık-fakirlik, neden-sonuç vb. gibi farklılaşma alanlarında hükmünün olmadığını düşünmemiz durumunda varlık, mahiyet sahibi bir bileşik olarak anlaşılacaktı. Hâlbuki varlık öyle bir şeydir ki -aynı zamanda her şeydir- bireyleri arasındaki farklılığı oluşturduğu gibi onların arasındaki birliği de oluşturmaktadır. Şu halde mevcutların bireysel farklılıkları zihinde mahiyetlere atfedilirken diş dünyada ise bu farklılaşmalar teşkîk niteliğine atfedilmektedir. Zihnin varlık hakkında teşkîke düşmesinin sebebi ise varlığın herhangi bir mahiyetinin olmadığı, bunun yanında zihinsel bütün mahiyetlerin dış dünyada tahakkuk edebilmesi için kendisine muhtaç olmasıdır.

Varlıkta teşkîkin meşhur formülü olan "varlık, mevcutların birleşmelerini ve farklılaşmalarını sağlayan asıldır" önermesinin felsefi ve tasavvufi gelenekteki ifade biçimi olan "varlık mertebeleri" veya "hazarât-1 hams" hakkında şu söylenebilir. Varlık mertebeleri; piramitsel bir dizilim içerisinde tek olan varlığın taayyünleri olmaları yönünden homojen; mertebeleri oluşturan dizilimleri açısından ise heterojen bir görünüme sahiptir. Sonuç olarak varlığın teşkîki niteliğini kabul etmek, varlığın zihin tarafından yakalanması imkânsız, akışkan, basit, belirsiz ve yaratıcı olduğunu kabul etmektir. Varlık teşkîki niteliği sayesinde mevcutların aralarında barındırdıkları nitelik, nicelik vb. gibi arazi, kategorilere dayanan cins, fasıl ve türsel ayrımlara da tâbi değildir. Tam aksine bu sayılanlar varlığın teşkîk niteliğinin bir ürünüdür.

\section{Kaynakça}

Aristoteles. Metafizik. çev. Ahmet Arslan. İstanbul: Sosyal Yayınları, 2014.

Aristoteles. Organon. çev. Hamdi Ragıp Atademir. 5 Cilt, Ankara: Milli Eğitim Basımevi, 1963.

Âli Yâsîn, Ca'fer. el-Fârabî fi hudûdihi ve rusûmihi. Beyrut: Âlemü'l-Kütüb, 1985.

Cihan, Ahmet Kamil. “Sühreverdî’nin Nur ve İnsan Düşüncesi”. Doğu'dan Batı'ya Düşüncenin Serüveni. ed. Eyüp Bekiryazıc1. 7/975-990. İstanbul: İnsan Yayınları, 2015.

Corbin, Henry. İslâm Felsefesi Tarihi (Başlangıcından İbn Rüşd'ün Ölümüne). çev. Hüseyin Hatemi. İstanbul: İletişim Yayıncılık, 1994.

Cürcânî, Seyyid Şerif. Kitâbü't-Ta'rîfât. Beyrut: Dâru'l-Kitâbü'l-Arab, 1983.

Descartes. Felsefenin İlkeleri. çev. Mesut Akın. İstanbul: Say Yayınları, 1995.

Fârâbî. Kitâbü'l-hurûf (Harfler Kitabı). çev. Ömer Türker. İstanbul: Litera Yayıncılık, 2018.

Fârâbî. el-Medînetü'l-fâzıla. çev. Yaşar Aydınlı. İstanbul: Litera Yayıncılık, 2018.

Fârâbî. "Kitâbü'l-cedel" el-Manțıkıyyetü'l li'l-Fârâbî, Thk. Muhammed Tâki Dânişpejûh. Kum: Mektebetü Âyetüllahü'l-Uzmâ el-Mar'aşî el-Necefî, 1408.

Fazlur Rahman. The Philosophy of Mullā Sadrā. New York: State University of New York Press, 1975.

Görkaş, İrfan. “Farabi Metafiziğinde Varlık (El-Mevcûd) Terimi ve Eklentileri”. Bozok Üniversitesi İlahiyat Fakültesi Dergisi 6/11 (2017), 67-90. 
Güler, Aliye. Fârâbî, İbn Sînâ ve Gazzâlî Mantığında Dilbilim Kavramları. İstanbul: Marmara Üniversitesi, Sosyal Bilimler Enstitüsü, Yüksek Lisans Tezi, 2015.

Hillî, Allâme. Cevherü'n-naḍ̂d fi şerḥi Manțiki'l-tecrid. nşr. Muhsin Beydarfar. Kum: İntişarat-1 Beydar, 1430.

Izutsu, Toshihiko. İslam'da Varlık Düşüncesi. çev. İbrahim Kalın. İstanbul: İnsan Yayınları, 1995.

İbnü'l-Arabî. Fusûsü'l-Hikem. çev. Nuri Gençosman. İstanbul: MEB Yayınları, 1992.

İbn Rüşd. Metafizik Büyük Şerhi. çev. Muhittin Macit. İstanbul: Litera Yayıncılık, 2016.

İbn Sînâ. Dânişnâme-i Alầ. çev. Murat Demirkol. İstanbul: Türkiye Yazma Eserler Kurumu Başkanlığ 1 Yayınları, 2013.

İbn Sînâ. el-işârât ve'n-tenbîhât mea şerhịi Nașîruddin et-Tûsî. nşr. Süleyman Dünya. 4 Cilt. Kahire: Dâru'l-Meârif, 1985.

İbn Sînâ. Kategoriler. çev. Ömer Türker. İstanbul: Litera Yayıncılık, 2014.

İbn Sînâ. Metafizik. çev. Ekrem Demirli-Ömer Türker. İstanbul: Litera Yayıncılık, 2017. İbn Sînâ. et-Ta'lîkâat. nşr. Abdurrahman Bedevi. Beyrut: ed-Daru'l-İslâmiyye, 1972.

Kalın, İbrahim. Varlık ve İdrak, Molla Sadrâ'nın Bilgi Tasavvuru. çev. Nurullah Koltaş. İstanbul: Klasik Yayınları, 2013.

Kuşçu, Ali. Şerḥü Tecrîdi'l-'akā'id. nşr. Muhammed Hüseyin Zirâî Rizâyî. Kum: İntişârâtı Râid, 1393.

Küyel, Mübahat Türker. Fârâbî'nin Peri Hermeneias Muhtasarı. Ankara: Atatürk Kültür Merkezi Yayını, 1990.

Mâcit, Muhittin. “Teşkîk”. Türkiye Diyanet Vakfı İslâm Ansiklopedisi 40/567-568. İstanbul: TDV Yayınları, 2011.

Molla Sadrâ. Arşa Ait Hikmetler. çev. Fevzi Yiğit. İstanbul: Önsöz Yayıncılık, 2019.

Molla Sadrâ, el-Hikmetü'l-müte'âliye fî esfâri'l-erba'a. thk. Ali Ekber Reşad. Tahran: Bunyâd-i Hikmet-i İslâmi-yi Sadrâ, 1380.

Molla Sadrâ. Kitâbü'l-meşâir (Metafiziğe Giriş). çev. Ahmet Kamil Cihan - Salih Yalın Fevzi Yiğit. İstanbul: Endülüs Yayınları, 2019.

Molla Sadrâ. Şerḥu ve ta'lîkâtü Șadrü'l-müte'ellihîn İlâhiyyâti'ş-Şifấ' nşr. Necefkulu Habibi. 2 Cilt. Tahran: Bunyâd-i Hikmet-i İslâmi-yi Sadrâ, 1382.

Molla Sadrâ. "eş-Şevâhidü'r-rubûbiyye", Mecmû'a-yi resâ'il-i felsefî-yi Șadrü'l-müte'ellihîn. thk. Hamid Naci İsfehanî. Tahran: Bunyâd-i Hikmet-i İslâmi-yi Sadrâ, 1389.

Musa b. Meymûn. Delâletü'l-hâîîn. çev. Osman Bayder - Özcan Akdağ. Kayseri: Kimlik Yayınevi, 2019.

Mustafa, İbrahim. vd.. el-Mu'cemü'l-vasît. İstanbul: Çağrı Yayınları, 1989.

Mutahhari, Murtaza. Felsefe Dersleri 2. çev. Ahmet Çelik. İstanbul; İnsan Yayınları, 1999.

Pirinç, Ahmet. Molla Hâdi Sebzevâri'nin Metafizik Görüşleri. Elazı̆̆: Fırat Üniversitesi, Sosyal Bilimler Enstitüsü, Doktora Tezi, 2015.

Râğib el-İsfehânî. Müfredât elfâzi'l-Kur'ân. nşr. Safvân Adnân Dâvudî. Dimeşk: Daru'lKalem, 1992.

Sebzevârî, Hâdî-i. Şerhü̈'l-Manzûme. nşr. Cevâd Âmulî. İran: Neşrinâb, 1369.

Sebzevârî, Abbas Ali. “Tâlik" Niḥ̂yyetü'l-hikme. Kum: Müessesetü Neşri'l-İslâmî, 1434.

Sühreverdî. "Hikmetü'l-İşrâḳ" Mecmû'âtü Mușannefâti Şeyhi İşrâk. nşr. Henry Corbin. Tahran: Pijûhişgâh-1 Ulum-i İnsâni ve Mutâla'ât-1 Ferhengi, 1373. 
78 | Fevzi Yiğit

Sühreverdî. Hikmetü'l-İşrak: İşrak Felsefesi. çev. Tahir Uluç. İstanbul: İz Yayıncılık, 2009. Tabâtabâî, Muhammed Hüseyin. Nihâyetü'l-hikme. nşr. Abbas Ali Sebzevârî. Kum: Müessesetü Neşri'l-İslâmî, 1434.

Sadreddin Konevî. Yazışmalar. çev. Ekrem Demirli. İstanbul: İz Yayıncılık, 2002.

Yezdî, Muhammed Tâkî Misbâh. el-Menhecü'l-cedîd fi ta'limi'l-felsefe. Nşr. Muhammed Abdü'l Münim el-Hakanî. Beyrut: Dârü't Teârifi li'l-Matbûât, 2008. 


\section{The Quality of Tashkīk of the Concept of Being in Ibn Sīnā and Mullā Șadrā}

\section{(Extended Abstract)}

In this article, the views of these five great philosophers on the subject of tash$k \bar{\imath} k$ will be examined. Al-Fārābī does not directly mention the nature of the concept, but his views on the concept of existence have paved the way for later philosophers. Ibn Sīnā accepted the concept to a certain extent; Tūsī tried to make these extensions clearer. It is Suhreverdī, who leads to the final results of the concept through the concept of $n \bar{u} r$. As for Mullā Șadrā, by interpreting an entire heritage that has reached him, he has given a final form to the matter. My conclusion is that the concept of existence or nūr is not subject to a universal concept, but is governed by its counterparts in the external world. In this respect, the concepts of tashkik are vital in establishing the connection between the mind and the outside world. The opinions of theologians who have a negative approach on the subject are excluded from the present study.

The issue of tashkik takes place on the discussion of whether the concept of existence should be said equally or gradually for all beings. The distinctions such as existence-quiddity and necessary-contingent are those developed for the same purpose. Another distinction is to attach the properties such as necessary, contingent, and hädith to beings when the name of the existent is said to them. In this way, both the name of the existent could be said to beings, and the differences between them become clear. Besides, the property of tashkik of existence is related to issues such as unity-multiplicity, simplicity, rank, substance, and accident.

As can be understood, the idea of tashkik can be said to have arisen as a result of two operations of the mind. In its first operation, the mind subordinates all its interlocutors ontologically to which it is said the name of existent. In the second, it attempts an ontological unification operation to prevent the resulting distinction from being sharp and impenetrable. Since these operations take place in existence, what ultimately separates and combines existing ones is the same. The mind, which sees that there is no choice other than using the same concept in terms of logical and linguistic terms, calls these concepts tashki $k$ because of the confusion in distinguishing them.

It can be seen that the distinction between existence-quiddity is quite useful in the dividing of beings, but not in combining them. That is why philosophers discuss the asāla between these two. Accordingly, existence or quiddity has the asāla as opposed to another, just like in the case of substance and accident. It can even be said that the power of this distinction is weak compared to the tashkik , since concepts like God, whose scope is almost identical to the concept of existence, cannot have a quiddity. 
Although there is no disagreement about the simple structure of existence, there are differences among Islamic philosophers in understanding that it is subject to tashkik. In this case, the underlying attitudes of philosophers concerning the distinction between existence and quiddity determined their attitudes towards tashkik. Existence's becoming different in terms of strengthweakness, perfection-deficiency, priority-posteriority, need-wealth, cause-effect, etc. can be accepted as a different explanation of quiddity. However, this distinction has a more sound structure in that it does not encounter many difficulties faced by the distinction between existence and quiddity.

In order to compare the distinction between necessary and contingent with the issue of tashkik, all beings have been subjected to a dual classification. Besides, it is asserted that contingent beings received their existence from the Necessary Being in order to prevent the contraction from being experienced within the scope of the existence. In this case, either the possibilities have no existential value, or it must be said that the previous assertion presents an apparent inconsistency. Both situations are incompatible with external reality.

Tashkik in existence can be formulated as follows: "Existence is the principle that enables the unifying and differentiation of the existing." According to this, existence has to have an orderly existence in terms of its reality in the outside world. Existence is homogeneous in that it is the unity of the beings, which are arranged in a pyramidal plane and fill the stages, and that they are their foundations. On the other hand, it has a heterogeneous appearance in terms of attitudes such as relative sequences, priority-posteriority, perfectiondeficiency, and its state, form, and quality. In other words, to accept tashkik in existence is to accept that the existence has an impossible, fluid, simple, uncertain, and creative structure that cannot be captured by the mind. As a result, it can be said that the concept of existence or that of light is subject to tashkik not in terms of being a universal concept, but in terms of its reality outside world. In this respect, the concepts of tashkik are also vital in establishing the connection between the mind and the outside world. 